\title{
KEARIFAN LOKAL DALAM PENGELOLAAN SUMBER DAYA \\ PESISIR DAN LAUT \\ Hukum Adat Laot dan Lembaga Panglima Laot di Nanggroe Aceh \\ Darussalam
}

\author{
Maya Puspita \\ Program Magister Sumber Daya Pesisir Universitas Diponegoro \\ mpus2602@yahoo.com
}

\begin{abstract}
:
The fisherman communities of Aceh Nangroe Darussalam has been aware to manage their potential resources, their coast and seas for centuries equipped with local indigenous values tradition and culture, so-called 'traditional wisdom.' The traditional wisdom implied in this region includes the authority ground of Panglima Laot, fishing time determination and the system of marine management cooperated with local government. The sanction is also applied as a consequence of its violation. They respect the nature a lot and believe if they "treat" the nature wisely and gently, it will give them something in return. They well manage between the local indigenous values tradition and culture and management of coastal and marine resources in order to maintain the sustainability of the resources. Primarily, after the tsunami, the fishermen society became more cautious and aware to preserve the ocean along with the resources.
\end{abstract}

Key words: traditional wisdom, coastal management, Hukum Adat Laot, Panglima Laot, Aceh

\section{Pendahuluan}

Pengelolaan sumberdaya pesisir pada dasarnya memiliki tujuan untuk meningkatkan kesejahteraan seluruh masyarakat secara berkelanjutan, terutama komunitas masyarakat lokal yang bermukim di wilayah pesisir (coastal zone). Oleh karena itu, dalam pemanfaatan sumberdaya pesisir, aspek ekologi dalam hal kelestarian sumberdaya dan fungsi-fungsi ekosistem harus dipertahankan sebagai landasan utama untuk mencapai kesejahteraan tersebut. Pemanfaatan sumberdaya pesisir diharapkan tidak menyebabkan rusaknya fishing ground, spawning ground, maupun nursery ground ikan; selain itu juga tidak merusak fungsi ekosistem hutan bakau (mangrove), terumbu karang (coral reefs), dan padang lamun (sea grass) yang memiliki keterkaitan ekologis dengan keberlanjutan sumberdaya di wilayah pesisir. 
Berlakunya Undang-Undang No. 22 tahun 1999 yang kemudian diubah menjadi UU No.32 tahun 2004 tentang Pemerintah Daerah memberikan nuansa baru pembangunan di daerah, sehingga upaya pemanfaatan dan pengembangan berbagai potensi daerah, termasuk potensi sumberdaya di wilayah pesisir, mulai mendapat perhatian. Arti penting dari UU tersebut adalah bahwa daerah memiliki otoritas yang lebih besar terhadap pengelolaan sumberdaya di wilayah laut. Seperti diketahui bahwa selama rezim orde baru (1966-1998) pengelolaan sumberdaya tersebut cenderung bersifat sentralistik, sehingga telah terjadi berbagai kerusakan sumberdaya hayati laut, seperti gejala tangkap lebih (overfishing), degradasi ekosistem terumbu karang dan hutan mangrove akibat praktik penangkapan ikan yang berlebihan dan merusak ekosistem perairan laut seperti pengeboman dan bahan-bahan beracun menjadi kurang terkontrol. Dengan diberlakukannya UU No. 32 tahun 2004, kebijakan pengelolaan sumberdaya pesisir dan lautan sudah bergeser dari sentralistik ke desentralistik.

Perubahan paradigma pembangunan pesisir dan lautan dari pola sentralistik ke desentralistik atau istilah lainnya kebijakan kelautan berbasis otonomi daerah, menghasilkan konsekuensi pemerintah kabupaten/kota kini telah memiliki kewenangan (authority) yang lebih besar dalam sistem pengelolaan perikanan artisanal. Dalam kebijakan pembangunan masyarakat pesisir, Pemerintah Daerah diharapkan akan berupaya untuk mengedepankan aspirasi, kebutuhan dan kepentingan masyarakat pesisir setempat (local coastal community), dan pelestarian sumberdaya alam dan lingkungan dalam rangka meningkatkan kesejahteraan masyarakat pesisir setempat (coastal community well-being), terutama rumah tangga nelayan artisanal (Wahyono, dkk., 1993).

Selain itu juga, perhatian terhadap hak-hak kepemilikan (property rights) dalam sistem pengelolaan perikanan artisanal (artisanal fisheries), dan kajian pola interaksi antar pemangku kepentingan (stakeholders) di wilayah pesisir, serta dampaknya terhadap komunitas nelayan artisanal sudah saatnya menjadi perhatian. Kemudian tatanan kelembagaan sosial tradisional yang hidup di lingkungan masyarakat nelayan bisa lebih dikembangkan, dan diakui keberadaannya dalam sistem hukum dan aturan-aturan (rules) sistem pengelolaan wilayah pesisir (Suhana, 2008).

\section{Pengertian Kearifan Lokal}

Dalam pengertian kamus, kearifan lokal (local wisdom) terdiri dari dua kata: kearifan (wisdom) dan lokal (local). Dalam Kamus Inggris Indonesia John M. Echols dan Hassan Shadily, local berarti setempat, sedangkan wisdom (kearifan) sama dengan kebijaksanaan. Secara umum maka local wisdom (kearifan setempat) dapat dipahami sebagai gagasan- 
gagasan dan nilai-nilai setempat (local) yang bersifat bijaksana, penuh kearifan, bernilai baik, yang tertanam dan diikuti oleh anggota masyarakatnya.

\section{1. Local Genius sebagai Local Wisdom}

Dalam disiplin antropologi dikenal istilah local genius yang merupakan istilah yang mula pertama dikenalkan oleh Quaritch Wales. Para ahli budaya membahas pengertian local genius ini, seperti Haryati Soebadio yang mengatakan bahwa local genius adalah juga cultural identity, identitas/kepribadian budaya bangsa yang menyebabkan bangsa tersebut mampu menyerap dan mengolah kebudayaan asing sesuai watak dan kemampuan sendiri (Ayatrohaedi, 1986); sementara Mundardjito (1985, dalam Ayatrohaedi, 1986) mengatakan bahwa unsur budaya daerah potensial sebagai local genius karena telah teruji kemampuannya untuk bertahan sampai sekarang. Ciri-cirinya adalah sebagai berikut: (1) mampu bertahan terhadap budaya luar, (2) memiliki kemampuan mengakomodasi unsur-unsur budaya luar, (3) mempunyai kemampuan mengintegrasikan unsur budaya luar ke dalam budaya asli, (4) mempunyai kemampuan mengendalikan, dan (5) mampu memberi arah pada perkembangan budaya.

Adat kebiasaan pada dasarnya teruji secara alamiah dan niscaya bernilai baik, karena kebiasaan tersebut merupakan tindakan sosial yang berulang-ulang dan mengalami penguatan (reinforcement). Apabila suatu tindakan tidak dianggap baik oleh masyarakat maka ia tidak akan mengalami penguatan secara terus-menerus. Pergerakan secara alamiah terjadi secara sukarela karena dianggap baik atau mengandung kebaikan. Adat yang tidak baik hanya akan terjadi apabila pelakunya mengalami pemaksaan oleh penguasa. Bila demikian maka ia tidak tumbuh secara alamiah tetapi dipaksakan.

Sistem kearifan tradisional atau pengetahuan masyarakat lokal didasarkan atas beberapa karakter penggunaan sumberdaya (Matowanyika, 1991), ialah (1) sepenuhnya pedesaan, (2) sepenuhnya didasarkan atas produksi lingkungan fisik setempat, (3) integrasi nilai ekonomi, sosial, budaya serta institusi dengan hubungan keluarga sebagai kunci sistem distribusi dan keluarga sebagai dasar pembagian kerja, (4) sistem distribusi yang mendorong adanya kerjasama, (5) sistem pemilikan sumberdaya yang beragam, tetapi selalu terdapat sistem pemilikan bersama, dan (6) sepenuhnya tergantung pada pengetahuan dan pengalaman lokal.

\section{2. Konsepsi Kearifan Lokal di Indonesia}

Secara konsepsional kearifan lokal yang berkembang di Indonesia atau yang lebih dikenal dengan Hak Ulayat Laut (HUL) merupakan terjemahan dari bahasa Inggris, sea tenure. Seorang pakar kelautan, Laundsgaarde menyebutkan bahwa istilah sea tenure mengacu kepada seperangkat hak dan kewajiban timbal balik yang muncul dalam 
hubungannya dengan kepemilikan wilayah laut. Selanjutnya Sudo (1983) mengatakan bahwa sea tanure merupakan suatu sistem, di mana beberapa orang atau kelompok sosial memanfaatkan wilayah laut, mengatur tingkat eksploitasinya termasuk melindunginya dari eksploitasi yang berlebihan (over exploitation). Oleh karena itu melengkapi batasan Sudo, Akimido (1991) mengatakan bahwa hak-hak kepemilikan (property rights), mempunyai konotasi sebagai memiliki (to own), memasuki (to acces), dan memanfaatkan (to use).

Kearifan lingkungan dapat diwujudkan dalam nilai sosial, norma adat, etika, sistem kepercayaan, pola penataan ruang tradisional, serta peralatan dan teknologi sederhana ramah lingkungan. Sumber daya sosial yang diwarisi secara turun temurun tersebut, pada kenyataannya terbukti efektif menjaga kelestarian lingkungan, serta menjamin kelestarian lingkungan sosial. Kondisi itu dapat dicontohkan melalui pranata sasi di Maluku yang digunakan untuk melindungi kawasan perairan dan didukung oleh peran kewang sebagai penegak sasi. Tak kalah penting adalah efektivitas teknologi rotasi perladangan yang dikembangkan masyarakat dayak di Kalimantan dalam memulihkan kesuburan tanah atau rempong dammar sebagai model konservasi yang dikembangkan masyarakat Kruy di Lampung Barat. Masyarakat Kubu di Jambi atau dikenal Orang Rimbo memperoleh Kalpataru tahun 2006. Penghargaan ini diberikan Presiden RI karena peran Orang Rimbo mengamankan Taman Nasional Bukit Duabelas dengan menerapkan teknologi hampongan sebagai upaya membentengi hutan Taman Nasional Bukit Duabelas dari penjarahan liar.

Konotasi semacam ini tidak hanya mengacu pada wilayah penangkapan (fishing ground), tetapi juga mengacu pada tehnik-tehnik penangkapan, peralatan penangkapan, teknologi yang digunakan bahkan sumberdaya yang ditangkap dan dikumpulkan. Dalam perspektif ini, secara ringkas dapat dikatakan bahwa HUL merupakan seperangkat aturan atau praktik pengelolaan atau manajemen wilayah laut dan sumberdaya yang terkandung di dalamnya. Perangkat aturan atau praktek HUL ini menyangkut siapa yang memiliki hak atas suatu wilayah, jenis sumberdaya dan teknik pengeksploitasian sumberdaya tersebut. Jadi, pertanyaan pokok dalam kajian HUL ini adalah siapa yang menguasai laut (wilayah, jenis sumberdaya, teknologi dan tingkat eksploitasi) dan bagaimana serta dengan cara apa menguasainya.

Studi tentang HUL juga perlu memperhatikan aspek dinamikanya dalam arti perubahan sebagai pranata lokal yang berkaitan dengan aspek sosial, budaya, teknologi, ekonomi dan politik masyarakat nelayan tempat HUL tersebut berada. Jadi terdapat hubungan fungsional antara HUL dengan aspek-aspek kultur lainnya. Namun pendekatan fungsional yang dimaksud di sini bukan sebagai sistem yang tertutup, tetapi sebagai general system theory 
(Bennet, 1976 dalam Saad, 1994) yaitu suatu sistem yang terbuka sesuai dengan karakter masyarakat maritim yang mobil, namun sekaligus pula dicirikan oleh interaksi sosio-budaya yang bersifat sistemik (Antariksa, 1995).

Suhana (2008) menyimpulkan bahwa variabel-variabel pokok dalam kajian HUL adalah menyangkut (1) wilayah, (2) unit pemilik sosial, (3) legalitas beserta pelaksanaannya (enforcement). Wilayah dalam konteks pengaturan HUL tidak hanya terbatas pada pembatasan luas wilayah, tetapi juga pada eksklusivitas wilayah, yang dapat juga berlaku pada sumberdaya kelautan, teknologi yang digunakan, tingkat eksploitasinya dan batas-batas yang bersifat temporal.

Selanjutnya Wahyono (2000, dalam Suhana, 2008) mengatakan bahwa pemegang hak dalam kasus HUL menunjukkan bahwa di berbagai tempat yang berbeda terdapat keanekaragaman baik secara individu, kelompok kekerabatan, komunitas desa, sampai negara. Hal yang menarik dari unit pemegang hak ini adalah masalah transferabilitas yaitu bagaimana hak eksploitasi dialihkan dari suatu pihak ke pihak lain, dan pemerataan (equity) yaitu pembagian hak ke dalam satu unit pemegang hak.

\section{Masyarakat Adat dalam Perspektif UU No 27 Tahun 2007}

Undang-udang No 27 Tahun 2007 tentang Pengelolaan Wilayah Pesisir dan PulauPulau Kecil telah mempertimbangkan keberadaan masyarakat adat untuk teribat dalam pengelolaan sumberdaya pesisir dan pulau-pulau kecil. Dalam undang-undang tersebut didefinisikasn bahwa masyarakat adat adalah kelompok masyarakat pesisir yang secara turuntemurun bermukim di wilayah geografis tertentu karena adanya ikatan pada asal-usul leluhur, adanya hubungan yang kuat dengan Sumber Daya Pesisir dan Pulau-Pulau Kecil, serta adanya sistem nilai yang menentukan pranata ekonomi, politik, sosial, dan hukum. Artinya bahwa kelompok masyarakat lokal seperti Suku Bajo dan para pelaku sasi termasuk ke dalam kelompok masyarakat adat tersebut.

Pasal 61 menyatakan bahwa Pemerintah mengakui, menghormati, dan melindungi hakhak Masyarakat Adat, Masyarakat Tradisional, dan Kearifan Lokal atas Wilayah Pesisir dan Pulau-Pulau Kecil yang telah dimanfaatkan secara turun-temurun. Artinya bahwa keberadaan masyarakat adat saat ini sudah mendapatkan perhatian yang sangat baik oleh pemerintah. Namun demikian besarnya perhatian pemerintah tersebut harus dibarengi dengan berbagai upaya untuk terus meningkatkan kesejahteraan masyarakat adat.

Dalam pasal 18 UU/27/2007 dijelaskan bahwa masyarakat adat diberikan hak untuk memiliki Hak Pengusahaan Perairan Pesisir (HP-3). Selain itu juga HP-3 juga diberikan kepada orang perseorangan atau kepada badan hukum yang didirikan berdasarkan hukum 
Indonesia. Sementara itu dalam Rancangan Peraturan Pemerintah (RPP) tentang Tatacara Pemberian, Pendaftaran, dan pencabutan HP-3 dijelaskan bahwa Hak Pengusahaan Perairan Pesisir yang diberikan kepada Masyarakat Adat, luasnya memperhatikan wilayah pengelolaan hak ulayat yang berlaku secara turun-menurun di perairan pesisir dan tidak bertentangan dengan peraturan perundang-undangan, kepentingan umum, kepentingan bangsa dan negara, serta kepentingan bersama dari rakyat (Pasal 16).

Dalam RPP HP-3 tersebut juga dijelaskan hal-hal yang perlu diperhatian dalam pengajuan HP-3 oleh masyarakat adat, seperti harus menyampaikan data/dokumen yang dapat dibuktikan kebenarannya meliputi ikatan asal-usul berdasarkan ginealogis, norma adat yang masih berlaku, dan wilayah perairan pesisir yang telah dikelola secara turun-temurun, serta pranata kelembagaan adat dan sistem hukum yang masih diakui (Pasal 21). Keberadaan persyaratan ini dirasakan akan memberatkan masyarakat adat dalam melindugi wilayahnya lewat HP-3, karena pada umumnya berbagai norma adat dan berbagai aturan adat lainnya belum dilakukan secara tertulis. Artinya pemerintah sebelum memberlakukan persyaratan tersebut perlu ada berbagai upaya untuk mendampingi masyarakat adat dalam mendokumentasikan berbagai aturan adat tersebut. Tanpa adanya upaya tersebut dikhawatirkan keberadaan masyarakat adat akan termarginalkan oleh aturan yang telah dibuat oleh pemerintah tersebut.

\section{Hukum Adat Laot dalam Pengelolaan Sumber Daya Kelautan dan Perikanan}

Dalam konsep hukum adat di Aceh, lingkungan hidup merupakan anugerah Allah SWT yang memiliki nilai strategis bagi kehidupan manusia dan makhluk hidup lainnya. Keberadaan lingkungan hidup menjadi bagian integral dari kelangsungan hidup makhluk hidup itu sendiri, termasuk manusia di dalamnya, sehingga tidak dapat ditawar-tawar bila eksistensi lingkungan hidup harus senantiasa terjaga kelestariannya. Pengelolaan lingkungan hidup yang arif dan bijaksana telah dipraktekkan sejak lama bahkan sudah berlangsung secara turun-temurun. Dalam melakukan pengelolaan lingkungan laut, lembaga adat Panglima Laot (laut) menerapkan nilai dan konsep kearifan lokal, yang hingga kini masih tetap dipertahankan.

\section{1. Lembaga Panglima Laot}

Dari segi nama, gelar panglima untuk pimpinan lembaga adat laot merupakan sebuah keistimewaan tersendiri. Setidaknya dari gelar tersebut sudah mencerminkan jabatan yang sarat dengan kekuasaan dan jabatan. Ini memang dapat dibuktikan dalam peran kesehariannya yang tegas, bahkan harus bersikap keras dalam mengambil setiap keputusan. Tidak ada keterangan yang pasti sejak kapan lembaga Panglima Laot masuk ke dalam sistem 
adat Aceh. Menurut beberapa sumber, lembaga ini sudah lama berkembang sejalan dengan perjalanan era kesultanan di Aceh di mana salah satu pendukung perangkat pemerintahan adalah lembaga adatnya. Begitu otonomnya Lembaga Panglima Laot, sehingga pada zaman Sultan Iskandar Muda (1607-1636 M) Panglima laot diangkat resmi oleh Sultan. Tugasnya selain memberdayakan ekonomi kawasan juga menjadi alat pertahanan dan keamanan di laot. Untuk mengembangkan tugas tersebut, Panglima laot diberi kekuasaan menyelenggarakan peradilan dan melaksanakan setiap putusan yang dibuatnya (Djuned, 1995). Dalam buku De Atjehers, Snouck Hurgronje hanya menyebutkan bahwa para pawang yang mengkoordinir kegiatan penangkapan ikan di laot dipimpin oleh seorang Panglima Laot beserta perangkatnya yang dipilih oleh para pawang di wilayah teupin mereka masing-masing. Wilayah hukum (adat) seorang Panglima disebut Lhok, antara satu Lhok dengan Lhok lainnya dipisahkan oleh tanda batas alam (Hurgronje, 1985 dalam Anonimous, 2007).

\section{2. Peranan Panglima Laot dalam Pengelolaan Lingkungan Laut}

Lembaga Panglima Laot berkedudukan di wilayah laut dan berfungsi mengatur pengelolaan sumber daya alam di wilayah pesisir dan laut. Selain itu, Panglima Laot juga berfungsi membantu pemerintah daerah dalam menyukseskan pembangunan perikanan, melestarikan adat-istiadat dan kebiasaan-kebiasaan dalam masyarakat nelayan. Dalam melaksanakan fungsinya, Panglima Laot mempunyai tugas, antara lain memelihara dan mengawasi ketentuan-ketentuan hukum adat dan adat laut; mengkoordinasikan dan mengawasi setiap usaha penangkapan ikan di laut; menyelesaikan perselisihan/sengketa yang terjadi di antara sesama anggota nelayan atau kelompoknya; mengurus dan menyelenggarakan upacara adat laut; menjaga/mengawasi agar pohon-pohon di tepi pantai jangan ditebang; merupakan badan penghubung antara nelayan dengan pemerintah; dan meningkatkan taraf kehidupan nelayan pesisir pantai.

Dalam melakukan pengelolaan lingkungan pesisir dan laut, Panglima Laot berpegang teguh pada hukum adat laut. Hukum adat laut adalah aturan-aturan adat yang dipelihara dan dipertahankan oleh masyarakat nelayan untuk menjaga ketertiban dalam penangkapan ikan dan kehidupan masyarakat nelayan di pantai. Hukum adat laut juga dapat berfungsi sebagai pengisi hukum positif nasional, apabila dalam hukum nasional tidak ada pengaturan mengenai hal itu. Substansi kaedah adat laut adalah kaum nelayan bersama kemampuan yang mereka miliki berupa pengetahuan alat tangkap, pengelolaan sumberdaya hayati laut dan kemampuan menjaga kelestarian sumber potensi yang tersedia di alam bebas.

Wilayah kekuasaan Panglima Laot mulai dari wilayah pesisir pantai hingga ke laut lepas. Ruang fisik wilayah pesisir pantai yang menjadi kewenangan Panglima Laot meliputi 
bineh pasie (tepi pantai), leun pukat (kawasan untuk tarik pukat darat), kuala dan teupien (tepian pendaratan perahu, baik di kawasan teluk maupun kuala), dan laot luah (laut lepas). Menurut Djuned (1995), wilayah kekuasaan Panglima Laot ke arah laut lepas pada prinsipnya mengikuti kaedah hukum sejauh mana sumber daya laut itu bisa dikelola secara ekonomis oleh masyarakat adat laut. Sedangkan ruang fisik yang berhubungan dengan ekosistem pantai meliputi uteun bangka (hutan bakau), uteun pasie, uteun aron (hutan cemara), neuheun (tambak), dan lancang sira (ladang garam).

Bineh pasie (tepi pantai) adalah kawasan di tepi pantai terhitung mulai dari pecahnya ombak hingga ke tempat di mana tanaman tahunan tidak bisa tumbuh, paling hanya ditumbuhi oleh tanaman tapak kuda. Bineh pasie merupakan kawasan darat yang berada dalam pengawasan adat laut karenanya penggunaan dan perubahan peruntukan kawasan bineh pasie untuk kepentingan selain kepentingan masyarakat nelayan haruslah atas persetujuan dari masyarakat nelayan setempat. Bineh pasie merupakan wilayah kewenangan lembaga Panglima Laot untuk mengatur dan mengawasi pemanfaatannya, khususnya untuk kesejahteraan kaum nelayan. Kawasan bineh pasie sangat dipengaruhi oleh faktor alam seperti abrasi. Salah satu faktor yang mempercepat terjadinya abrasi adalah akibat ditebangnya pohon pelindung di pantai yang dahulunya dipelihara secara turun-temurun untuk kebutuhan kayu industri dapur arang, bahan bangunan dan pembukaan areal tambak rakyat. Abrasi membuat areal bineh pasie menjadi semakin sempit.

Leun pukat adalah kawasan bineh pasie yang digunakan untuk kegiatan menarik pukat darat (pukat banting atau pukat Aceh). Leun pukat letaknya membujur dari tepi pantai hingga laut yang ukurannya sesuai dengan kebutuhan mendaratkan ikan bagi pukat darat. Leun pukat merupakan kawasan yang dilindungi oleh adat dan tidak boleh dipergunakan untuk keperluan lain tanpa izin dari masyarakat nelayan.

Teupien merupakan tempat nelayan mendaratkan perahunya. Pendaratan perahu ini bisa saja di kuala atau di bineh pasie. Kuala yang menjadi kewenangan adat laut adalah bagian yang secara tradisional digunakan untuk mendaratkan perahu yang digunakan sebagai jalur perahu menuju laut dari tepian pendaratan. Sebagai salah satu pusat kegiatan nelayan di saat pulang melaut, penggunaan teupin diatur dan dilindungi oleh adat. Dengan demikian, kepentingan nelayan atas kawasan ini tetap terpelihara dan terjamin keberadaannya.

Uteun bangka (hutan bakau) merupakan kawasan penyanggga bagi kehidupan di pesisir pantai. Tanaman ini memiliki berbagai fungsi di antaranya sebagai tempat berbiaknya berbagai jenis ikan dan udang, pencegah penyusupan air laut ke daratan dan juga menahan abrasi. Di beberapa tempat seperti di Kabupaten Aceh Besar dan Aceh Barat berlaku adat, 
siapa yang menanam pohon bakau di suatu perairan, maka yang bersangkutan berhak atas tanaman tersebut. Namun karena pengelolaannya tidak terkontrol, penanaman pohon bakau terus meluas, sehingga tidak jelas lagi kepemilikannya. Pohon bakau yang sudah besar ditebang oleh pemiliknya untuk di jadikan neheun (tambak). Kondisi ini menyebabkan luas hutan bakau milik ulayat masyarakat semakin berkurang, akibatnya pelestarian bakau untuk perlindungan ekosistem pantai menjadi sulit dilakukan karena beralihnya kepemilikan atas hutan bakau yang ada di wilayah setempat.

Uteun Aroen (hutan cemara) merupakan kawasan penyangga di tepi pantai yang terdiri dari pohon cemara. Perairan yang dekat dengan pesisir pantai yang banyak pohon cemara berdasarkan pengalaman nelayan setempat diyakini sangat disukai oleh kawanan ikan tertentu, terutama molusca (kerang-kerangan), kakap, kerapu dan lain-lain sebagai habitat ikan-ikan tersebut yang lebih tertarik kepada suhu iklim sekitar kawasan pantai yang ditumbuhi pohon cemara.

Uteun pasie (hutan pantai) adalah sebutan untuk kawasan tajuk pepohonan hutan yang tumbuh di pinggir pantai. Uteun pasie merupakan kawasan hutan yang dilindungi untuk kepentingan keseimbangan lingkungan di kawasan pesisir.

Masyarakat pesisir di Aceh memiliki kearifan lokal dalam mengatur pemanfaatan kawasan pesisir di antaranya melalui perlindungan jalur hijau berupa pepohonan di sepanjang pantai yang sekarang lebih dikenal dengan istilah green belt. Pada masa lalu, jalur hijau berupa bak aron (pohon cemara) dilindungi oleh adat. Barang siapa melakukan penebangan terhadap bak aron di bineh pasie (tepi pantai), maka ia dikenakan sanksi adat. Pada saat ini, adat tentang pemeliharaan dan perlindungan bak aron mulai kurang dipedulikan sehingga banyak bak aron yang ditebang. Padahal menurut pengalaman para pawang, bak aron memiliki fungsi ekologis yang baik untuk menciptakan keseimbangan lingkungan di kawasan pesisir. Daya adaptasinya yang tinggi terhadap iklim pesisir dan air laut membuat bak aron dapat bertahan hidup walaupun tanah tempat tumbuhnya digenangi air laut, misalnya pada saat air pasang. Manfaat terpenting dari segi ekonomi, adanya jalur hijau berupa bak aron menimbulkan daya tarik jenis ikan tertentu untuk mendekati kawasan pantai. Keadaan ini sangat menguntungkan nelayan karena mereka dapat menangkap ikan di perairan terdekat. Manfaat lainnya, bak aron dapat memperkuat tebing atau ikatan tanah di sepanjang pantai yang ditumbuhinya. Berdasarkan pengalaman pasca tsunami, bak aron ternyata dapat bertahan dari genangan air tsunami. Hal ini dapat kita lihat di sekitar Pantai LhokngaLampuuk, Kecamatan Lhoknga, Kabupaten Aceh Besar.

Selain bak aron, menurut responden, ada beberapa jenis tanaman lainnya yang baik 
ditanami di zona penyangga (tepi pantai) seperti bak siron, bak bunot, bak seukee dan mangrove atau bangka (bakau). Tanaman tersebut dapat ditanam di tanah pantai yang kering maupun di kawasan pasang surut. Di tanah pantai yang kering, di tepi pantai dapat ditanami bak siron, bak bunot dan bak seukee, sementara di kawasan basah atau payau dikembangkan tanaman jenis bakau. Pola penanaman kesemua tanaman tersebut dapat dibuat dalam bentuk yang bervariasi, baik dalam bentuk jalur yang seragam maupun campuran. Bila menggunakan pola jalur seragam maka susunannya sebagai berikut: bak aron di lapisan dalam, di tengah ditanami bak bunot bervariasi dengan bak siron dan di bagian paling luar yang berhadapan langsung dengan laut ditanami bak seukee. Dengan pola ini, apabila timbul tanoh jeut (tanah yang timbul atau bertambah di tepian sungai atau tepi pantai sebagai akibat proses alam), maka akan disusul pula pelebaran pertumbuhan bak seuke secara alamiah, sehingga tanoh jeut tersebut lama-kelamaan menjadi semakin kokoh ikatannya dan dapat ditanami tanaman tua (Anonimus, 2008).

Dari segi pola tumbuh, bak aron pertumbuhannya bersifat vertikal ke atas dan membentuk batang yang kokoh, sedangkan bak siron membentuk tajuk yang rindang dan adakalanya batangnya merunduk ke arah laut. Akar bak siron memiliki sifat mengikat tanah ke arah samping memanjang sepanjang tebing, dengan demikian ia dapat memperkuat tebing atau tepi pantai. Manfaat ekonomis dari bak siron belum banyak dikembangkan. Dari sejumlah tanaman yang sesuai untuk pembangunan jalur hijau di tepi pantai sebagai zona penyangga, bak bunot merupakan salah satu pohon yang memiliki nilai yang cukup strategis di masa depan. Tanaman ini termasuk tanaman yang memberikan sumbangan besar bagi kelanjutan industri perkapalan di masa depan karena bak bunot merupakan salah satu kayu terbaik untuk pembuatan perahu atau kapal ikan. Selama ini, para tukang perahu mengandalkan bak bunot manee (pohon laban) untuk dijadikan geunandeng (kerangka kapal). Padahal, saat ini, bak manee yang memenuhi syarat untuk bahan perahu semakin sulit dicari. Berbeda dengan bak manee, bak bunot dapat tumbuh di kawasan pesisir, bahkan di tepi pantai yang terkena siraman air laut sekalipun. Batangnya yang dapat tumbuh membesar memberi nilai tambah jika dijadikan tanaman pelindung (benteng alam) di zona penyangga.

Selama ini tidak ada larangan adat bagi nelayan untuk menangkap ikan di sebuah lhok, yang ada hanyalah pengaturan eksplorasi penangkapan yang meliputi pengaturan waktu penangkapan, tata cara penangkapan dan penggunaan alat tangkap sesuai dengan adat laut setempat. Bagi nelayan di luar lhok tersebut wajib tunduk dan mengikuti ketentuan adat dari wilayah adat laut di mana ia melakukan usaha penangkapan ikan saat itu. Ketentuanketentuan yang diatur dalam hukum adat laut adalah sebagai berikut. 


\section{3. Kenduri Adat Laut dan Hari Pantang Laut}

Kenduri adat laut dilaksanakan paling kurang 3 (tiga) tahun sekali atau tergantung kesepakatan dan kesanggupan nelayan setempat; dinyatakan 3 (tiga) hari pantang melaut pada acara kenduri tersebut dihitung sejak ke luar matahari pada hari kenduri hingga tenggelam matahari pada hari ketiga. Ketentuan-ketentuan adat yang lain adalah sebagai berikut.

(1) Pada hari Jum'at dilarang melaut selama 1 (satu) hari terhitung sejak tenggelam matahari pada hari kamis hingga terbenam matahari pada hari Jumat.

(2) Pada Hari Raya Idul Fitri dilarang melaut selama 2 (dua) hari dihitung sejak tenggelam matahari pada hari Meugang hingga terbenam matahari pada hari kedua Hari Raya.

(3) Pada Hari Raya Iedul Adha dilarang melaut selama 3 (tiga) hari dihitung sejak tenggelam matahari pada hari meugang hingga terbenam matahari pada hari ketiga Hari Raya.

(4) Pada Hari Kemerdekaan 17 Agustus dilarang melaut selama 1 (satu) hari dihitung sejak tenggelam matahari pada tanggal 16 Agustus hingga terbenam matahari pada tanggal 17 Agustus.

(5) Setiap tanggal 26 Desember dilarang melaut selama 1 (satu) hari dihitung sejak tenggelam matahari pada tanggal 25 Desember hingga terbenam matahari pada tanggal 26 Desember. Larangan ini untuk mengenang peristiwa tsunami yang terjadi pada tanggal 26 Desember 2004.

(6) Sanksi hukum. Bagi nelayan yang melanggar hari pantang laut dikenakan sanksi hukum berupa seluruh hasil tangkapan disita dan dilarang melaut serendah-rendahnya 3 (tiga) hari dan selama-lamanya 7 (tujuh) hari.

(7) Adat Pemeliharaan Lingkungan Laot sebagai berikut:

(a) dilarang melakukan pemboman, peracunan, pembiusan, penglistrikan, pengambilan terumbu karang dan bahan-bahan lain yang dapat merusak lingkungan hidup ikan dan biota lainnya; (b) dilarang menebang/merusak pohon-pohon kayu di pesisir pantai laut seperti pohon arun/cemara, pandan, ketapang, bakau dan pohon lainnya yang hidup di pantai; (c) dilarang menangkap ikan/biota laut lainnya yang dilindungi (lumba-lumba, penyu dan lain sebagainya); (d) dilarang menggunakan jaring di area terumbu karang (daerah pemijahan); (e) adanya pengaturan penangkapan ikan yang bertanda (tagging). Larangan-larangan tersebut masih berlaku efektif dalam masyarakat nelayan.

\section{4. Sistem Pengelolaan Lingkungan Laut oleh Lembaga Panglima Laot}


Pengelolaan lingkungan laut menurut hukum adat laut dipercayakan kepada Lembaga Adat Laot, yang dipimpin oleh seseorang yang ahli dalam bidang pengelolaan laut yang disebut Panglima Laot. Dalam menjalankan pengelolaan lingkungan laut, Panglima Laot dibantu oleh Pawang Pukat dan Aneuk Pukat yang tersusun dalam suatu struktur organisasi. Lembaga Adat Laot merupakan suatu persekutuan hukum adat laut. Sebagai suatu lembaga hukum, maka lembaga tersebut berkuasa mengatur eksploitasi dan perlindungan lingkungan dan sumber daya hayati laut di dalam wilayah laut yang menjadi kekuasaannya. Kekuasaan mengatur lingkungan laut di wilayah kekuasaannya bersifat otonom dan tidak tergantung kepada kekuasaan lainnya. Kekuasaan Panglima Laot meliputi 3 (tiga) bidang, yaitu bidang keamanan di laut, bidang sosial warga persekutuan dan bidang pemeliharaan lingkungan laut. Sistem pengelolaan lingkungan laut oleh Lembaga Panglima Laot dilakukan sebagai berikut.

\section{(1) Penetapan aturan hukum pengelolaan lingkungan laut}

Setiap aspek kegiatan di laut diatur dengan hukum Adat Laot. Aturan-aturan itu ada yang telah lama dipertahankan dan ada pula yang dibuat baru sesuai dengan perkembangan kebutuhan hukum dari masyarakat nelayan.

Aturan yang telah lama ada, seperti larangan menebang pohon di tepi pantai dan pantangan turun ke laut pada hari-hari tertentu. Pada dasarnya setiap orang bebas turun ke laut, bekerja mencari nafkah. Akan tetapi, atas pertimbangan kebebasan menjalankan syariat Islam dan keamanan bagi setiap anggotanya, maka hukum yang dipertahankan ada hari-hari yang dilarang melaut, yaitu hari Jumat, 17 Agustus, hari besar Islam, dan hari-hari dalam peristiwa kecelakaan di laut sebagaimana telah disampaikan. Pada hari Jumat dilarang melaut atas alasan agama dan keamanan di laut. Alasan agama, agar pada hari Jumat setiap anggota nelayan berkesempatan menunaikan shalat Jumat.

Aturan lainnya adalah tentang tata cara penangkapan ikan. Sebuah perahu atau kapal yang ingin menangkap sekawanan ikan, pawang dari perahu atau kapal tersebut harus memberi tanda (isyarat) kepada kapal lain. Tanda atau isyaratnya adalah dengan mengangkat tangan atau tudung kepala ke atas; tanda atau isyarat itu memberi hak kepada kapal bersangkutan untuk menangkap kawanan ikan tersebut dan sekaligus timbul larangan bagi perahu lain untuk menangkap kawanan ikan itu.

Aturan yang dibuat baru berupa larangan menangkap ikan dengan menggunakan alat tangkap jenis trawl, bahan peledak, penglistrikan, racun serta larangan membuang limbah seperti oli bekas ke laut.

\section{(2) Pemimpin yang menjalankan Hukum Adat Laot}

Hukum tanpa kekuasaan adalah bukan hukum, karena hukum tanpa kekuasaan, tidak 
dapat dipaksakan keberlakuannya di dalam masyarakat. Dalam sistem pengelolaan lingkungan laut, pengelolaan dipimpin oleh Panglima Laot. Kekuasaan mengatur pengelolaan lingkungan laut dilaksanakan oleh suatu organisasi yang terstruktur secara vertikal dari Aneuk Pukat, Pawang Pukat dan Panglima Laot. Panglima Laot merupakan pimpinan tertinggi dalam struktur organisasi itu dan bertanggung jawab atas pelaksanaan pengelolaan lingkungan laut, sehingga prinsip kelestarian lingkungan dapat terjamin serta semua hukum dan peraturan pemerintah berjalan. Jadi, semua nelayan baik sebagai Aneuk Pukat maupun sebagai Pawang Pukat dan Panglima Laot ikut serta bersama-sama mengawasi pelaksanaan pergelolaan lingkungan laut sesuai ketentuan Hukum Adat Laot.

\section{(3) Pengadilan untuk mempertahankan Hukum Adat Laot.}

Setiap tindakan yang bertentangan dengan ketentuan Hukum Adat diadili oleh Pengadilan Panglima Laot dan diberi sanksi. Sanksi yang diberikan bukanlah sanksi terhadap fisik, akan tetapi berupa perampasan hasil tangkapan atau larangan bekerja di laut selama waktu tertentu.

\section{(4) Menjalin hubungan dengan intansi pemerintah}

Panglima Laot dalam melaksanakan pengelolaan lingkungan laut bekerja sama dengan Dinas Kelautan dan Perikanan, Syahbandar dan polisi perairan. Segenap fungsionaris Lembaga Adat Laot mendapat bimbingan dari Dinas Kelautan dan Perikanan, baik mengenai teknologi penangkapan hasil laut maupun dalam pelaksanaan peraturan pemerintah, terutama yang menyangkut pengelolaan lingkungan laut seperti pemilikan jaring yang tidak merusak lingkungan dan daerah penangkapan ikan.

Syahbandar sebagai penanggung jawab terhadap pelayaran di laut sangat berkepentingan kepada Panglima Laot. Karena itu izin pembuatan perahu/kapal dan pos berlayar bagi perahu/kapal disalurkan melalui Panglima Laot dan pelaksanaannya diawasi bersama. Syahbandar memberi petunjuk-petunjuk wilayah laut yang boleh dilayari dan boleh untuk menangkap ikan serta tentang cuaca di laut. Kerja sama dengan polisi perairan dilakukan dalam hal adanya pelanggaran berat dan tidak mampu diselesaikan oleh Panglima Laot, seperti adanya kapal asing menangkap hasil laut dalam wilayah perairan Indonesia yang setelah diperingatkan oleh fungsionaris Panglima Laot tetap tidak mengindahkan; kasus seperti itu dilaporkan kepada polisi perairan. Mengingat peran serta Panglima Laot demikian besar dalam menjaga pelestarian fungsi laut, maka keberadaan Lembaga Panglima Laot tetap dipertahankan oleh masyarakat. Hal ini berarti kewenangan Panglima Laot tetap diakui dalam pengelolaan lingkungan laut. Dalam hukum adat laot telah dikembangkan sistem pelaporan untuk menjaga lingkungan laut. Jika seorang nelayan atau anggota masyarakat 
lainnya melihat ada oknum yang melanggar lingkungan hidup, maka pelanggaran tersebut harus dilaporkan segera pada Panglima laot dan/atau kepada pihak yang berwajib.

Panglima Laot secara kelembagaan mengatur pengelolaan lingkungan laut dengan aturan selain memuat larangan juga mengatur cara orang bertindak terhadap lingkungan dalam lingkup yang terbatas sesuai dengan kewenangan yang dimilikinya. Pengaturan seperti itu membawa konsekuensi lebih efektifnya hukum atas pengelolaan lingkungan laut.

\section{Simpulan}

Keberadaan dan peranan kearifan tradisional dalam masyarakat nelayan Nangroe Aceh Darussalam memiliki strukturisasi yang jelas dan tertata sedemikian rupa. Mereka menyadari betul arti penting dari alam dan manfaatnya bagi kehidupan mereka. Oleh karena itu, kearifan tradisional di tengah-tengah kehidupan mereka dijalankan dengan penuh tanggung jawab dan kesadaran. Selain itu, pemimpin, Panglima Laot yang telah ditunjuk oleh masyarakat nelayan telah membina hubungan yang harmonis dengan pemerintah dan instansi-instansi terkait. Dengan kerja sama ini, Panglima Laot dapat melaksanakan tugasnya lebih baik karena jika terdapat pelanggaran-pelanggaran yang tak bisa diatasinya sendiri, Panglima Laot melaporkannya kepada pihak berwajib.

Eksistensi hukum adat ini masih berlaku sampai saat ini, bahkan semenjak pasca tsunami, masyarakat wilayah pesisir makin peduli dan berusaha untuk menjaga lingkungan mereka lebih baik lagi. Sistem pengelolaan lingkungan semacam ini sangat bagus dan terbukti cukup berhasil, dikarenakan dasar dari sistem hukum adat laut ini adalah kesadaran dan kepedulian yang mendalam dari masyarakat atas lingkungan sekitar mereka yang telah memberikan banyak keuntungan dan manfaat demi keberlangsungan hidup mereka.

\section{Daftar Pustaka}

Anonimous. 2007. "Dokumen Analisis Kebijakan Sumber Daya Kelautan dan Perikanan Nanggroe Aceh Darussalam. Green Coast for Nature and People after The Tsunami. Banda Aceh: WWF-Indonesia \& Wetlands International Indonnesia Programme.

Antariksa, IGP. 1995. Hak Ulayat Laut Masyarakat Maritim Kecamatan Pulaupulau Kei Kecil Kabupaten Maluku Tenggara, Maluku. Jakarta: PMB-LIPI No.845.

Ayatrohaedi. 1986. Kepribadian Budaya Bangsa (local genius). Jakarta: Pustaka Jaya. 
Djuned, T. 1995. "Pengelolaan Lingkungan Laut Oleh Panglima Laot (Suatu Studi Di Kotamadya Banda Aceh)." Laporan Penelitian. Darussalam-Banda Aceh: Universitas Syiah Kuala.

Suhana. 2008. "Belajar dari Suku Bajau dan Kearifan Lokal Desa Autubun Kepulauan Tanimbar Maluku Tenggara Barat." Kebijakan Ekonomi Kelautan pada Pusat Kajian Suberdaya Pesisir dan Lautan. Jakarta: PKSPL-IPB.

Saad S. 1994. "Rompong suatu tradisi penguasaan perairan pantai pada masyarakat Bugis-Makasar," dalam Jurnal Era Hukum No.2 Tahun 1/Oktober 1994. Jakarta: Fakultas Hukum Universitas Tarumanegara.

UU No 27 Tahun 2007 tentang Pengelolaan Wilayah Pesisir dan Pulau-Pulau Kecil.

Wahyono, A., Sudiyono dan F.I Thufail. 1993. "Aspek-aspek Sosial Budaya Masyarakat Maritim Indonesia Bagian Timur. Hak Ulayat Laut Desa Para, Kecamatan Manganitu, Sangihe Talaud.” Jakarta: PMB-LIPI No. 4: 51. 